\title{
Food for Thought ...
}

\section{E-Cigarettes and the Need and Opportunities for Alternatives to Animal Testing}

\section{Thomas Hartung}

Johns Hopkins Bloomberg School of Public Health, Center for Alternatives to Animal Testing (CAAT), Baltimore, MD, USA, and CAAT-Europe, University of Konstanz, Germany

\begin{abstract}
Summary
E-cigarettes have become within only one decade an important commodity, changing the market of the most masskilling commercial product. While a few years ago estimates suggested that in the course of the $21^{\text {st }}$ century one billion people would die prematurely from tobacco consumption, e-cigarettes continuously gaining popularity promise 10-30fold lower health effects, possibly strongly changing this equation.

However, they still are not a harmless life-style drug. Acceptability simply depends on whether we compare their use to smoking or to not-smoking. In the absence of long-term follow-up health data of users, additional uncertainty comes from the lack of safety data, though this uncertainty likely only is whether they represent 3 or $10 \%$ of the risk of their combustible counterpart. This means that there is little doubt that they represent a prime opportunity for smokers to switch, but also that their use by non-smokers should be avoided where possible.

The real safety concerns, however, are that e-cigarettes expose their users to many compounds, contaminants and especially flavors (more than 7,000 according to recent counts), which have mostly not been tested, especially not for long-term inhalation exposure. Neither the precautionary traditional animal testing nor post-marketing surveillance will offer us data of sufficient quality or sufficiently fast to support product development and regulatory decisions. Thus, alternative methods lend themselves to fill this gap, making this new product category a possible engine for new method development and its implementation and validation.
\end{abstract}

Keywords: tobacco, electronic cigarettes, safety testing, alternative methods, non-animal methods

\section{Introduction}

Around $30 \%$ of current cancer deaths in the US are caused by tobacco. Every year 695,000 Europeans die prematurely of tobacco-related causes ${ }^{1}$. It is estimated that, in terms of economic impact, smoking costs the EU countries at least $€ 100$ billion per year. According to the World Health Organization, tobacco is "the only legally available product that kills up to one half of its regular users when consumed as recommended by its manufacturer." As Kurt Vonnegut phrased it, "Cigarettes are a classy way to commit suicide", though "classy" might be contested by those enduring the smoke and they might prefer H. M. Forester (in Game of Aeons) "Smoking is suicide by installments."

My father died from cigarette smoking - lung cancer - when I was 23. I have little sympathy for this product (though to be fully honest, I enjoy one or two Havana cigars per year). Ecigarettes comprise a number of devices, which typically use a battery to heat a cartridge with a nicotin-containing solution ("e-liquid" or "e-juice"), which is thus vaporized for inhalation. The first-generation devices are disposable or rechargeable. The second-generation e-cigarettes contain tank systems with larger batteries for prolonged use. Finally, the third-generation consists of large-capacity batteries and integrated circuits, allowing users to control the amount of nicotine per puff. Thus, the newer generation tools alleviate the concern about billions of small batteries ending in our trash somewhat.

E-cigarettes are taking over the market with an astonishing pace. They started only about ten years ago as a spin-off from advances in battery technology from mobile phones, which can now provide sufficient power to vaporize an adequate flow of liquid and sufficient battery life to make devices practical ${ }^{2}$. In

\footnotetext{
1 http://ec.europa.eu/health/tobacco/docs/eurobaro_attitudes_towards_tobacco_2012_en.pdf

2 www.clivebates.com/documents/vapebriefingv3.docx
}

Received June 29, 2016;

http://dx.doi.org/10.14573/altex.1606291

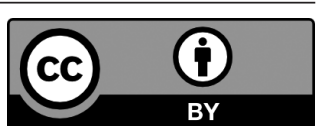

This is an Open Access article distributed under the terms of the Creative Commons Attribution 4.0 International license (http://creativecommons.org/ licenses/by/4.0/), which permits unrestricted use, distribution and reproduction in any medium, provided the original work is appropriately cited. 
2014, already 460 brands were counted (Zhu et al., 2014). In 2015 in Europe, $20.3 \%$ of current smokers, $4.7 \%$ of ex-smokers, and $1.2 \%$ of never cigarette smokers in the EU reported having ever used an e-cigarette (overall approximately 29.3 million adults) (Vardavas et al., 2015). In the same year, the market was estimated at $\$ 3.5$ billion $^{3}$. Estimates by Bonnie Herzog from Wells Fargo suggest that sales might exceed those of traditional tobacco products by $2021^{4}$. In the US, a recent survey supported by the FDA and the Centers for Disease Control and Prevention shows current e-cigarette use among high school students has skyrocketing from 1.5 percent in 2011 to 16 percent in $2015^{5}$. The future use will depend on accessibility, taxation and bans, i.e., policy decisions. Is this a means to cease smoking only prescribed by physicians or a lifestyle drug of minor danger? This article will touch on this question, but will focus mainly on testing needs and the (possible) role of animal models and their alternatives.

As a disclaimer: I have not worked on (and not used) any of these products myself, but was attracted to the topic early on due to my annual lecture on addiction within a course on $\mathrm{Hu}-$ man Biology at the University of Konstanz, Germany, which I started 20 years ago. Some pointed comments to my friend Aidan Gilligan led him to include me in the series of events on science politics organized on the topic by his company Sci$\mathrm{Com}^{6}$; three concise brochures available for download from his website nicely summarize the science / policy battlefield of these new products. In consequence I had the honor to serve on a number of American Association for the Advancement of Science (AAAS) ${ }^{7,8,9}$, European Science Open Forum $(\mathrm{ESOF})^{10}$ and World Science Forum (WSF) symposia and their press points targeting especially journalists to contribute a toxicologist's view on the topic. Most recently, I was invited to write two editorials for Chemistry World and Scientific American (Hartung, 2016a,b). This is how a topic finds you, not how you find the topic...

In parallel, the increasing interactions with representatives from the tobacco industry in all areas of alternative methods were notable; obviously, this industry is embracing the new approaches to safety testing and sometimes even spearheads them as will be discussed later. Their representatives are now in the boards of organizations promoting alternative methods and (co-)organize the respective conferences. This is a remarkable change in a field where some ten years ago financial contributions to conferences by tobacco industry where hidden or even returned - in one case to make my keynote lecture possible to which my university objected because of tobacco industry contribution. Today it is impossible to be active in our field without working with the respective colleagues. This is very different though to taking their money for research or our own events.

\section{Background on smoking and e-cigarettes}

Cigarettes are the most predominant combustible use of tobacco, beside cigars, pipes, water pipes, Bidis (cheap cigarettes made of unprocessed tobacco wrapped in leaves) or Kreteks (cigarettes made with a blend of tobacco, cloves and other flavors). Here, I will compare essentially to cigarette smoking only.

The SPECIAL EUROBAROMETER 385 “Attitudes of Europeans towards Tobacco"1 shows that as of March 2012, 28\% of the EU population smoke (32\% males and $24 \%$ females), including 29\% of young Europeans aged 15-24; they consume an average of 14.2 cigarettes per day. Half the respondents have never smoked $(51 \%)$ and a fifth $(21 \%)$ have given up smoking. The report states "There were no significant differences in the frequency of smoking in comparison to autumn 2009. The absolute majority of $69 \%$ of EU citizens have heard of electronic cigarettes. $46 \%$ say they also know what they are, while $23 \%$ do not know exactly what an e-cigarette is. $31 \%$ admit they have not heard of this product. ... EU citizens are uncertain of the health risks of e-cigarettes. A relative majority (38\%) answers 'don't know' when asked whether they think they are harmful or not. Just over a quarter (27\%) assumes that these cigarettes are harmful to the health of those who use them while 35\% think this is not the case." Although smoking has decreased in highincome countries, smoking prevalence is increasing in the developing world, with more than $80 \%$ of the world's smokers living in low- and middle-income countries ${ }^{11}$.

Smoking is a known risk factor for numerous diseases such as various cancers, cardiovascular and pulmonary diseases, respiratory infections, GI ulcers, osteoporosis, reproductive disorders, and diabetes. Brooke Shields nicely said, "Smoking kills. If you're killed, you've lost a very important part of your life."

\section{The health effects of nicotine}

There are many different ways of ingesting nicotine (Carr, 2014) without burning tobacco: Chewing tobacco, snuff, Swedish-style snus, tobacco strips and some dissolvable to-

\footnotetext{
3 http://www.namastetechnologies.com/wp-content/uploads/2015/11/2.-WellsFargo-Vaporizer-Research-Report.pdf

4 http://www.nacsonline.com/Media/Daily/Pages/ND0917134.aspx\#.V1qYjlen6Xw

5 http://www.fda.gov/ForConsumers/ConsumerUpdates/ucm450882.htm

6 http://www.sci-com.eu/home/index.php

7 https://www.elsevier.com/connect/are-e-cigarettes-harmful-or-helpful

8 http://www.aaas.org/news/science-races-catch-e-cigarettes-popularity

9 http://www.science20.com/news_articles/ban_them_or_embrace_them_ecigarettes_face_a_fork_in_the_road-153217

$10 \mathrm{http}: / /$ www.euroscientist.com/e-cigarettes-regulatory-doldrums/

11 http://www.who.int/tobacco/mpower/tobacco_facts/en/
} 
bacco products. There is also a number of more or less pure nicotine products, most for smoking cessation, such as transdermal patches, gums, sublingual tablets, nicotine gels, nasal sprays, nicotine lozenges (usually flavored tablets containing nicotine that dissolve slowly in the mouth), nicotine water inhalers, nicotine wafers, nicotine lollipops and even nicotine lip balms. However, these cannot address the sensory and behavioral aspects of the smoking ritual, thus limiting their efficacy. E-cigarettes (ENDS = electronic nicotine delivery system; electronic cigarettes) are different as they are not primarily a cessation device, but a mass-marketed lifestyle drug. The first record of an e-cigarette dates to 1963, when Herbert A. Gilbert registered a patent on a "smokeless non-tobacco cigarette." Forty years later, in 2003, the Chinese pharmacist Hon Lik invented the current e-cigarette with patents held by the Chinese company Ruyan. Aggressive promotion over the Internet started in 2007, introducing e-cigarettes to the U.S. market and others. It is estimated that $30-50 \%$ of total e-cigarette sales are conducted online (Zhu et al., 2014).

Although nicotine is addictive, it's tar that kills. This is a common notion taught in medical schools (Benowitz, 2010), but probably it is not that simple. Nicotine is a psychoactive and highly addictive compound (Jasinska et al., 2014). Nicotine on its own is not very addictive (there is no strong evidence for addiction from many of the nicotine replacement products) and there are documented health effects of nicotine including cancer development (Campain, 2004). Adolescent exposure may actually be key to developing addiction.

The acute toxicity of nicotine to humans is still a matter of discussion. Recently, the human lethal dose was estimated to range between 6.5 and $13 \mathrm{mg}$ per $\mathrm{kg}$ body weight (b.w.), i.e., it is possibly higher than the widely accepted $1 \mathrm{mg}$ per kg b.w. (Mayer, 2014). The European Tobacco Product Directive (TPD) has recently been adopted after final negotiations between the European institutions: Upper limits were set to 20 $\mathrm{mg} / \mathrm{ml}$ and $200 \mathrm{mg}$ nicotine per refill-bottle. Thus e-cigarette cartridges can be acutely lethal at least for children (Kim and Baum, 2015) and the added flavors might mask the unpleasant taste of nicotine. However, of greater concern are obviously the long-term repeated low-dose exposures. A meta-analysis of 35 clinical trials found no evidence of cardiovascular or other life-threatening adverse effects caused by nicotine intake, and nicotine did not increase cardiovascular risk, even in patients with established cardiovascular disease (Farsalinos and Polosa, 2014). This is a key argument why e-cigarettes have been proposed as a harm reduction option when it comes to smoking. In fact, acute intoxications seem to be rare and mild (Cantrell, 2014). A major concern, little discussed in the context of e-cigarettes, is that recent studies have shown that nicotine can affect several important steps in the development of cancer, and suggest that it may cause aggravation and recurrence of the disease (Sanner and Grimsrud, 2015).

\section{The promise of e-cigarettes}

Studies suggest that one in three smokers who switch to ecigarettes reduce their consumption, and one in nine quit for good (personal communication Deborah Arnott, Chief Executive, Action on Smoking \& Health ASH UK) - numbers that will only rise as manufacturers increasingly make the experience mimic actual smoking. Even more impressive, the effectiveness of e-cigarettes for smoking cessation or reduction was examined in a survey of 222 smokers who had tried ecigarettes: 31\% reported smoking abstinence after 6 months and $67 \%$ reported a reduction in the number of cigarettes they smoked (Rom et al., 2015). A study following 40 switchers, showed sustained smoking abstinence after six months in $23 \%$, with $6 / 9$ still using the e-cigarette by the end of the study. Combined sustained 50\% reduction and smoking abstinence was shown in 22/40 (55\%) participants, with an overall $88 \%$ fall in cigarette per day (Polosa et al., 2011). Lower rates of smoking cessation and reduction rates were reported in a prospective one-year randomized control trial (RCT) evaluating 300 smokers who did not intend to quit. After one year, $10 \%$ of participants self-reported smoking reduction by $50 \%$ in the number of cigarettes per day and complete verified abstinence in $9 \%$ (Caponnetto et al., 2013). Interestingly, different nicotine contents of the e-cigarettes (one third even received nonicotine cartridges) showed no consistent differences. Many more studies could be cited, but there is no doubt that quite a few smokers who try e-cigarettes reduce their habit and sometimes even quit, whether they intended to at the beginning or not. Currently, e-cigarette users have to take larger, longer and slower puffs; this means different devices have different efficacy and there is room for improvement by engineering. Training of smokers also might make the experience approximate the one of smoking and thus make switching more appealing (Schroeder and Hoffman, 2014).

Burstyn (2014) reviewed over 50 publications and concluded that there is no evidence that vaping, i.e., using e-cigarettes, causes inhalable exposure to contaminants at levels that would warrant health concerns by the standards used to ensure safety in workplaces. Another matter of concern is the exposure of others in the vicinity of people vaping. It appears that the exposure to nicotine is ten-fold lower compared to the same situation close to cigarette smokers, and obviously there is no exposure to combustion products (Czogala et al., 2014).

Importantly, experiences in the UK suggest that almost no never-smokers use e-cigarettes and that growing experimentation amongst youth occurs almost entirely amongst smokers. Data from the US Center for Disease Control US from the National Youth Tobacco Survey 2011 and 2012 analyzed by Bates and Rodu ${ }^{12}$ show similar results: The data show a pronounced decline in cigarette smoking and in combined e-cigarette and cigarette prevalence between 2011 and 2012, as e-cigarette use

12 http://www.clivebates.com/?p=2053 
increased. Whether e-cigarettes are a potent weapon for smoking cessation or are simply a way for big tobacco to remain in business, depends on which studies you read.

If all smokers switched to e-cigarettes and current estimates about the risk of these products are accurate, cancer deaths would fall to only 1-2\% of users (Levy et al., 2004; McNeill et al., 2015). Sure, it's not advisable to inhale nicotine regularly, and our nine-year-old will not find an e-cigarette under the Christmas tree. But what makes e-cigarettes so controversial when it comes to public health?

\section{Matters of real concern}

Table 1 lists the promises and main concerns as to e-cigarettes. One key aspect is whether e-cigarettes represent a gateway to regular smoking and are making tobacco products more acceptable again. According to the US Centers for Disease Control and Prevention, around 2.4 million middle and high school students in the US were current users of electronic cigarettes in 2014. So we should not be surprised that kids try them, even before they try regular cigarettes. Flavors offered include cheesecake and strawberry - quite clearly showing the target group (though there is a study suggesting that flavors have no impact on nonsmoking teen's interest in e-cigarettes (Shiffman et al., 2015)). As most smokers pick up the habit as teenagers (Nelson, 2014), the availability of e-cigarettes to teens is worrisome because it may ultimately result in more smokers.

A major reason for the reduction of smoking in Western countries in recent years was not due to the introduction of ecigarettes but (beside strong taxation) that societal acceptability decreased. Smokers have been outlawed and forced outside of most public places. There is concern now that "safer smoking" could turn this trend and that the acceptance of e-cigarettes could lower our resistance toward other tobacco products. This explains why e-cigarettes are often not allowed in places, even where they do not really represent a nuisance to others.

An aspect currently not discussed too much is the electronic waste being produced, especially with the first generation of ecigarettes, with possible billions of batteries ending in the trash.
Also, the e-liquid cartridges possibly represent hazardous waste (Krause and Townsend, 2015).

\section{Safety assessments of e-cigarettes}

So, how dangerous are they? Nobody knows for sure. Some concerns were summarized by Callahan-Lyon (2014). A systematic review of available data, also in 2014, came to the conclusion (Orr, 2014): "Overall, the limited toxicology data on e-cigarettes in the public domain is insufficient to allow a thorough toxicological evaluation of this new type of tobacco product." Orr (2014) also listed the critical questions:

- What e-cigarette design features alter the production of and user exposure to different compounds and toxicants?

- Are e-cigarette users exposed to higher or lower levels of toxicants than conventional cigarette smokers?

- Are e-cigarette users exposed to higher or lower levels of toxicants than smokeless tobacco product users?

- Are e-cigarette users exposed to higher or lower levels of toxicants than users of nicotine replacement products, which are considered to be the safest nicotine delivery device (e.g., containing the least quantity of toxicants) on the US market today?

- What panel of exposure biomarkers should be used to determine e-cigarette toxicant exposure, disease risk, morbidity and mortality?

- What panel of exposure biomarkers should be used to compare different classes of tobacco products between tobacco product users and also non-users?

In summary, they ask for comparative exposure to toxicants, and the products to compare to, and the biomarkers to study in users. The rapid evolution of e-cigarette devices limits the assessment approach since traditional studies take time and are not suitable for chasing a moving target. In addition, the lack of manufacturing standards for e-liquids increases the variability in the composition of a particular mixture. The questions posed by Orr obviously leave two points out, which are the epidemiology and actual testing on animals or using alternative methods. Epidemiology based on outcome is difficult (and will not be dis-

Tab. 1: Promises and concerns of e-cigarettes

\begin{tabular}{|c|c|}
\hline Promise & Concern \\
\hline Lower risk tobacco product & Nicotine health effects \\
\hline Reduced consumption of other tobacco products & Acute nicotine intoxication (of children) chewing cartridges \\
\hline Bridge to cessation & Unknown health effects of flavors and other ingredients \\
\hline Reduced exposure to second hand smoke & Gateway to smoking \\
\hline \multirow[t]{4}{*}{ Additional markets for alternative methods } & Trash, especially batteries \\
\hline & Making smoking in general more acceptable again \\
\hline & Uncontrolled market with wild growth \\
\hline & Animal testing needs \\
\hline
\end{tabular}


cussed much further here): Lung cancer takes about 15 years to develop. Thus it will take more than 20 years until we know for sure how problematic e-cigarettes are. A large US governmentsponsored, 3-year observational trial - the PATH (Population Assessment of Tobacco and Health) study involving 59,000 people, smokers and nonsmokers, aged 12 years and older - is looking at how and why people start to use tobacco, how they quit, and why some people who quit start using tobacco again. But policy has to decide now. And this area will not be easy to study. How many cigarettes do you smoke and since when, is quite easy to answer. But many users combine e-cigarettes with the use of tobacco, and products change over time.

At the moment, we have to live with a guesstimate on the overall safety of e-cigarettes: About 3-5\% of the danger of cigarette smoking, some experts have proposed (Levy et al., 2004; McNeill et al., 2015). As quoted already, "nicotine addicts, tar kills," and there is no tar in e-cigarettes. But e-cigarette users do not only inhale nicotine. Flavors and additives are the big unknowns. The chemical picture is even more complex. E-cigarette aerosol is not water vapor as is often claimed; it is typically composed of varying flavors, with or without nicotine, diluted in a propylene glycol-, ethylene glycol- and/ or vegetable glycerol-based solution. The more frequently used propylene glycol and glycerol are considered relatively safe, though long-term studies are not available, but ethylene glycol, which is sometimes found in products, is widely used as an anti-freezing agent and is associated with pronounced toxicological risks (Hutzler et al., 2014). The e-liquid also can contain heavy metals and ultrafine particles, as well as carcinogens, such as the carbonyls, formaldehyde, acetaldehyde and acrolein (albeit at levels significantly lower than in cigarette smoke). Exposure to formaldehyde can even be as high as with conventional cigarettes, though one report found sixfold lower levels ${ }^{13}$. Additional additives, such as coumarin and acetamide, that raise concerns for human health, have been detected in certain samples (Hutzler et al., 2014). However, as to be expected, the exposure to toxicants is strongly reduced compared to smokers as, for example, assessed by biomarker analysis in urine (Hecht et. al., 2015). Although some toxins were present in e-cigarette vapor, the levels were 9-450 times lower than in regular cigarette smoke (Goniewicz et al., 2014): Polycyclic aromatic hydrocarbons were not detected in most products, tobacco-specific nitrosamines varied around 1/1000 the concentration of combustible tobacco products; volatile organic compounds in vapor were less than $1 \%$ of the threshold in workplace standards, and only acrolein was at $1 \%$ and formaldehyde between 0 and $3 \%$ of this threshold.

Cheng (2014) reviewed 29 earlier studies on the constituents of e-cigarettes and e-juices and concluded: "The levels of nicotine, tobacco-specific nitrosamines (TSNAs), aldehydes, metals, volatile organic compounds (VOCs), flavours, solvent carriers and tobacco alkaloids in e-cigarette refill solutions, cartridges, aerosols and environmental emissions vary considerably. The delivery of nicotine and the release of TSNAs, aldehydes and metals are not consistent across products. Furthermore, the nicotine level listed on the labels of e-cigarette cartridges and refill solutions is often significantly different from measured values. Phenolic compounds, polycyclic aromatic hydrocarbons and drugs have also been reported in e-cigarette refill solutions, cartridges and aerosols. Varying results in particle size distributions of particular matter emissions from e-cigarettes across studies have been observed. Methods applied for the generation and chemical analyses of aerosols differ across studies. Performance characteristics of e-cigarette devices also vary across and within brands." This shows the difficulty to come to any general conclusions and the need to set standards and hold the producers responsible for keeping them.

The range of additives and flavors used in the devices presents an enormous challenge. Two years ago, one count came up with 7,764 unique flavors available (Zhu et al., 2014). Noteworthy, in the 17 months between their searches, there was a net increase of 10.5 brands and 242 new flavors per month. Thus it is likely that in the meantime we have more than 10,000 flavors to which we have to add other constituents like additives such as preservatives, contaminants, and contact materials. Essentially, none of these flavorings have been tested to assess their risk to health; while many are food additives, just because they are safe when swallowed does not mean they are safe when inhaled chronically. E-cigarette manufacturers have relied on flavor ingredients with GRAS (generally recognized as safe) status with the U.S. Food, Drug, and Cosmetic Act. However, that is designated for ingredients added to food, which do not currently require premarket approval by the U.S. FDA. Noteworthy, there are attempts spearheaded by the Grocery Manufacturer Association and NSF to develop standards on how to assign GRAS status ${ }^{14}$, to which the author has the privilege to contribute. The GRAS status, however, is clearly not relevant for inhaled flavors. In many e-liquids, total flavor chemicals were found at $1-4 \%(10-40 \mathrm{mg} / \mathrm{ml})$, while nicotine was in the range of $0.6-2.4 \%$ (6 to $24 \mathrm{mg} / \mathrm{ml}$ ), and daily exposure to select flavors by vaping can exceed exposure limits established for work places (Tierney et al., 2015). A number of the flavor chemicals were aldehydes, which often are irritants for mucosal tissue of the respiratory tract. To date, only a few individual flavor compounds and hardly any mixtures (products) have been evaluated in the context of inhalation toxicology. Flavor industry has rightly taken a stand stating that these flavors, even if safe for foods (which we often do not know for sure either (Neltner et al., 2013)), are not evaluated for continued high-dose inhalation. However, they are still selling to the e-cigarette manufacturers....

A good example is diacetyl, a compound found in $75 \%$ of e-cigarettes tested (Allen et al., 2016). The substance is quite

$13 \mathrm{http}: / /$ ec.europa.eu/health/tobacco/docs/eurobaro_attitudes_towards_tobacco_2012_en.pdf

14 www.clivebates.com/documents/vapebriefingv3.docx 
Tab. 2: Advantages and disadvantages of different toxicological tools for e-cigarette testing and risk assessment

\begin{tabular}{|c|c|c|c|}
\hline Tool & Advantage / Promise & Disadvantage / Challenge & For e-cigarettes \\
\hline \multicolumn{4}{|l|}{ in silico } \\
\hline $\begin{array}{l}\text { Quantitative Structure/Activity } \\
\text { Relationships (QSAR) }\end{array}$ & $\begin{array}{l}\text { Cheap and fast; some working } \\
\text { models, e.g., mutagenicity }\end{array}$ & $\begin{array}{l}\text { Limited predictivity for few } \\
\text { endpoints, no validated ones; } \\
\text { not for natural substances and } \\
\text { mixtures }\end{array}$ & Few relevant models \\
\hline Read-across & Cheap and fast & $\begin{array}{l}\text { Depends on data availability, } \\
\text { only emerging good practices, } \\
\text { no validation; not for natural } \\
\text { substances and mixtures }\end{array}$ & Limited relevant data for flavors \\
\hline $\begin{array}{l}\text { Physiology-based pharma- } \\
\text { cokinetik (PBPK) and other } \\
\text { kinetic modeling }\end{array}$ & $\begin{array}{l}\text { Cheap; increasing integration } \\
\text { of in vitro test data }\end{array}$ & $\begin{array}{l}\text { To be done substance by } \\
\text { substance; not all organs well } \\
\text { modeled yet }\end{array}$ & Respiratory models challenging \\
\hline \multicolumn{4}{|l|}{ in vitro } \\
\hline 2D ("traditional" cell culture) & $\begin{array}{l}\text { Cheap and fast; increasing } \\
\text { access to high-quality human } \\
\text { primary cells and stem-cell } \\
\text { derived models }\end{array}$ & $\begin{array}{l}\text { Artificial conditions and limited } \\
\text { use of Good Practices; } \\
\text { reductionist models; lack of } \\
\text { metabolic capacities }\end{array}$ & $\begin{array}{l}\text { Many different models needed; } \\
\text { lung 2D models not very advanced }\end{array}$ \\
\hline $\begin{array}{l}\text { omics or high-content } \\
\text { imaging }\end{array}$ & Holistic analysis & $\begin{array}{l}\text { Making sense of data is difficult; } \\
\text { costly }\end{array}$ & $\begin{array}{l}\text { Depends on model availability } \\
\text { and quality; opportunity to } \\
\text { find unexpected effects }\end{array}$ \\
\hline $\begin{array}{l}\text { High-throughput screening } \\
\text { (HTS) }\end{array}$ & $\begin{array}{l}\text { Holistic analysis; mass-testing } \\
\text { of substances }\end{array}$ & $\begin{array}{l}\text { Few centers with individual, costly } \\
\text { set-ups; limited to simple in vitro } \\
\text { and in chemico assays; making } \\
\text { sense of data is difficult }\end{array}$ & $\begin{array}{l}\text { No testing platforms easily } \\
\text { available; no consensus on test } \\
\text { panels and interpretation }\end{array}$ \\
\hline 3D and organ-on-chip & $\begin{array}{l}\text { Organotypic culture conditions; } \\
\text { fueled by stem cell technologies } \\
\text { and bioengineering }\end{array}$ & $\begin{array}{l}\text { Only emerging, complex, } \\
\text { expensive }\end{array}$ & $\begin{array}{l}\text { Models, including lung, promising } \\
\text { but not standardized / widely } \\
\text { available / validated }\end{array}$ \\
\hline \multicolumn{4}{|l|}{ in vivo animal } \\
\hline Guideline studies & $\begin{array}{l}\text { Complexity of organism; } \\
\text { internationally harmonized }\end{array}$ & $\begin{array}{l}\text { Costly; long duration; limited } \\
\text { human relevance; statistically } \\
\text { underpowered and reproducibility } \\
\text { issues; few validated }\end{array}$ & $\begin{array}{l}\text { Strong differences in respiratory } \\
\text { system of rodents; inhalation } \\
\text { toxicology specially demanding }\end{array}$ \\
\hline Experimental & $\begin{array}{l}\text { Complexity of organism; } \\
\text { opportunities of genetic } \\
\text { manipulation }\end{array}$ & $\begin{array}{l}\text { Not standardized; unclear } \\
\text { predictivity for humans }\end{array}$ & $\begin{array}{l}\text { No smoking-induced lung cancer } \\
\text { model established }\end{array}$ \\
\hline \multicolumn{4}{|l|}{ in vivo human } \\
\hline Trials & Definitive answers possible & Limited durations possible; costs & $\begin{array}{l}\text { Ethically questionable except for } \\
\text { cessation studies }\end{array}$ \\
\hline Epidemiology & Relevance & $\begin{array}{l}\text { Long duration; changing exposure } \\
\text { patterns }\end{array}$ & $\begin{array}{l}\text { Too long; limited number } \\
\text { of studies possible }\end{array}$ \\
\hline \multicolumn{4}{|l|}{ Integrating tools } \\
\hline $\begin{array}{l}\text { Strategies and Integrated } \\
\text { Approaches to Testing and } \\
\text { Assessment (ITS, IATA) }\end{array}$ & $\begin{array}{l}\text { Synergistic information gain; } \\
\text { efficient use of resources }\end{array}$ & $\begin{array}{l}\text { Concepts for composition and } \\
\text { validation in infancy }\end{array}$ & $\begin{array}{l}\text { Promising but depends on } \\
\text { availability of building blocks; } \\
\text { point of reference unclear }\end{array}$ \\
\hline $\begin{array}{l}\text { Adverse Outcome } \\
\text { Pathways and Pathways } \\
\text { of Toxicity (AOP, PoT) }\end{array}$ & $\begin{array}{l}\text { Promotes mechanistic toxicology; } \\
\text { point of reference to organize } \\
\text { accepted toxicological knowledge }\end{array}$ & $\begin{array}{l}\text { More conceptual than a testing } \\
\text { tool; linear representations of } \\
\text { perturbed networks; few } \\
\text { established AOP; quality } \\
\text { assurance unclear }\end{array}$ & Could help ITS/IATA development \\
\hline $\begin{array}{l}\text { Systems toxicology, } \\
\text { virtual patients }\end{array}$ & $\begin{array}{l}\text { Models the complexity of an } \\
\text { organism; virtual experiments }\end{array}$ & Methods still in their infancy & $\begin{array}{l}\text { The bridge from big data to } \\
\text { big sense }\end{array}$ \\
\hline
\end{tabular}


well known - it is the butter flavor of popcorn. Although apparently safe when consumed, it is worth noting that inhalation of diacetyl has caused lung disease in workers producing the snack (known as "popcorn lung") (Egilman et al., 2007). While it is not clear whether the amounts inhaled by e-cigarette consumption could cause such conditions upon chronic use, diacetyl shows that there can be surprises when inhaling food flavors.

\section{Testing challenges}

Standardized testing paradigms for the e-liquid and e-cigarette aerosols have not been established; scientific consensus on the most appropriate testing paradigms for comparative analyses of e-cigarette products is critical (Orr, 2014). For cigarette smoking, standard puffing regimens and smoking protocols are available from various entities (Wan et al., 2009), but nothing comparable is available for e-cigarettes. A type of reference aerosol would be needed to compare different approaches and products to such a point of reference. For smoked tobacco products in general, the Cooperation Center for Scientific Research Relative to Tobacco (CORESTA) In Vitro Toxicology Task Force provided recommendations for a test battery (CORESTA, 2004), but this is not fully applicable to e-cigarettes, as it focused strongly on mutagenicity.

In a perfect world, we would start embarking on extensive trials of each and every one of the additives used, which would add considerably to the economy of animal testing and its alternatives (Bottini and Hartung, 2009, 2010). Figure 1 shows the different options for testing, which are listed in Table 2 together with general advantages and disadvantages as well as e-cigarette-specific remarks.

Traditional safety assessment would make use of animal testing as the main option. However, there are practical concerns that make this option difficult to achieve for the large number of substances relevant in this area. Inhalation toxicity

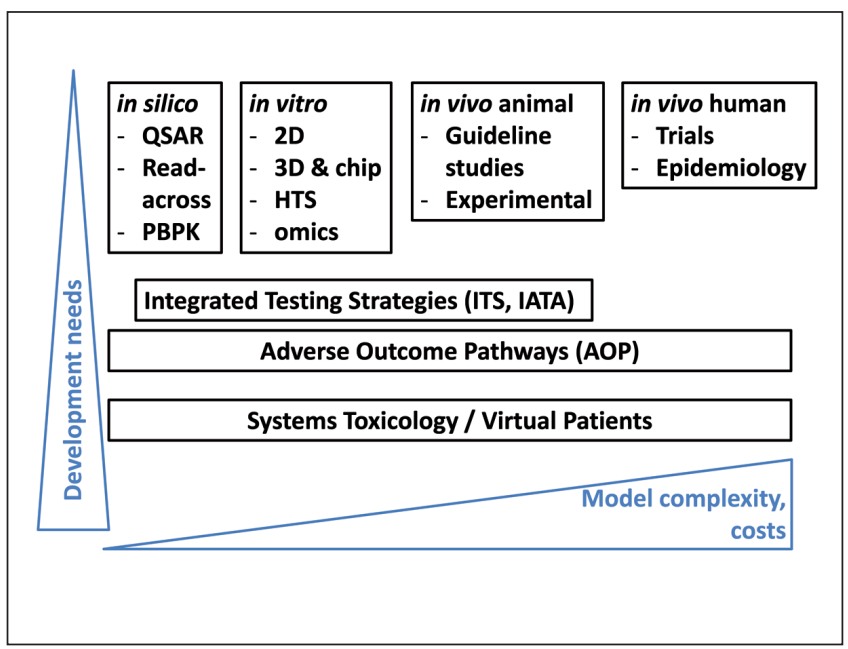

Fig. 1: The Toolbox of Toxicity Testing in the $21^{\text {st }}$ Century studies are very expensive and rodent cancer tests are even more so, costing around \$1 million per substance using the current standard method. An inhalation cancer study in either mice or rats costs about $\$ 2.5$ million per substance (personal communication Dr Costanza Rovida after consulting a CRO). This would amount to $\$ 4$ billion to test only all the flavorings available in 2014, $\$ 10$ billion if done as inhalation cancer studies. Even only a 90-day repeat dose inhalation study costs about \$300,000 per substance (Rovida and Hartung, 2009), amounting to $\$ 3$ billion for the estimated 10,000 flavors. At the same time, carcinogenicity studies using rats are not always predictive of human physiology, e.g., mice and rats predict each other only in 57\% of cases (Basketter et al., 2012; Leist et al., 2014). There is also no generally accepted animal model of smoking-induced lung cancer (Witschi, 2007), i.e., the most relevant effect of smoking cannot even be modeled in rodents. Furthermore, it takes four years or more to get results from cancer studies and they notoriously err on the side of safety. Due to the use of maximum tolerated doses, among others, the method is very precautionary, i.e., likely producing ten times more false than real positives (Basketter et al., 2012). For example, of more than 30 ingredients of coffee tested for carcinogenicity in rodents, more than $70 \%$ had a positive result. Does this mean we are regularly enjoying a brew of carcinogens? No - there is no such evidence! On the contrary, we live longer (Freedman et al., 2012) and studies even show that coffee reduces cancer risk: we have less liver cancer (Larsson and Wolk, 2007), melanoma (Loftfield et al., 2015) and basal cell carcinoma (Song et al., 2012), and to a lesser extent, premenopausal breast and colorectal cancers (Nkondjock, 2009) if we drink coffee. Typically, for whatever substance class was tested for carcinogenicity in rodents, around $50 \%$ of chemicals were positive. We have to imagine the percussions of such cancer findings for flavors, not only for their use in e-cigarettes but also in food. It cannot be in our interest to start mass-testing of flavors in rodent cancer bioassays.

The first step is clearly to understand what users are exposed to and these analyses have started (Goniewicz et al., 2014; Hutzler et al., 2014; Hahn et al., 2014). They are complicated because of the broad use of impure and natural compounds. Batch differences are unavoidable. Storage conditions will change them. Boiling will do so too. It is difficult to keep pace with the introduction of new flavors. Also, the vaping technologies change, altering the actual exposure.

Some animal studies are available, e.g., comparing three flavor formulations inhaled for 90 days in rats (Werley et al., 2016). At conditions, where at mid-dose level animals lost more than $10 \%$ body weight, there were a number of effects and some on nasal epithelia and bronchoalveolar lining fluid persisted after 42 days of recovery. The authors concluded: "In general, smoking-related effects upon the tissues in the respiratory tract are more adverse than those observed in our study, with increased incidence and severity". Another, more acute study in mice (Sussan et al., 2015) showed severe immunotoxicity of e-cigarette vapor. Mice that were exposed to e-cigarette vapor showed serum cotinine, a biomarker of nico- 
tine exposure, concentrations that were comparable to human e-cigarette users. Astonishingly, 20\% of the mice died, which shows once again that we are not $70 \mathrm{~kg}$-mice... Animal studies comparing e-cigarettes to non-smoking is probably the best way to discredit them.

So what else can we do instead of animal studies? The obvious first step is removing known toxicants (e.g., carcinogens). This means we should establish a negative list and limit, for example, the use of other substances (e.g., sensitizers). We will have to fill data gaps, using read-across and other in silico methods as well as in vitro (Wan et al., 2009) testing. Given the dynamic developments of this product category and the lack of established testing strategies, read-across is a prime opportunity for fast assessment and pruning of substances. The recent progress in this field (Patlewicz et al., 2014; Ball et al., 2016; Zhu et al., 2016) might form a starting point, though currently the necessary big datasets come from industrial chemicals (Luechtefeld et al., 2016) and drug development, e.g., in the e-Tox database ${ }^{15}$ (Cases et al., 2014). The common needs shared by e-cigarette industry with food, flavor, fragrance, cosmetics / personal care product industry to assess many overlapping ingredients and complex mixtures not really suitable for traditional toxicology, could synergize. A comprehensive database of available data would be an important step.

Johnson et al. (2009) made an inventory of then available in vitro tests, concluding: " $A$ variety of in vitro assays are available to assess tobacco smoke that address different modes of action, mostly using non-human cell models. However, smokeless tobacco products perform poorly in these assays. Although reliable as a screening tool for qualitative assessments, the available in vitro assays have been poorly validated for quantitative comparisons of different tobacco products". Our recent workshop summarized the available in vitro lung models (Gordon et al., 2015), many of which might be useful for studying inhalation toxicology. In the US, under the Family Smoking Prevention and Tobacco Control Act, the federal government, through the FDA Center for Tobacco Products $(\mathrm{CTP})^{16}$, started a science-based approach that addresses the complex public health issues raised by tobacco product regulation. Considerable funding (e.g., in 2013 they created 14 Tobacco Centers of Regulatory Science (TCORS) with \$326 million planned funding over six years) and efforts by e-cigarette manufacturers have most recently widened the portfolio of available assays, but an independent assessment of their fitness for purpose / validity is still missing.

Biological profiling similar to what ToxCast ${ }^{17}$ is doing in a multitude of biological assays in a high-throughput manner could be another step to identify possible liabilities. This stresses the need for such platforms being made available to industry. At less than $\$ 20,000$ per substance in ToxCast, this is an affordable expense compared to any traditional testing.

Applying these approaches not only to end-products but rather early in the selection of ingredients, as suggested in the Green
Toxicology approach (Maertens et al., 2014), is another important opportunity to make this more efficient.

The field of e-cigarettes presents itself as another area of tremendous testing needs, which cannot be satisfied by traditional regulatory testing. In vitro methods are starting to be applied (Cervellati et al., 2014; Palpant et al., 2015; Lerner et al., 2015; Ji et al., 2016). For this reasons, the area could become another engine for change, similar to nanotechnologies (Hartung, 2010a; Hartung and Sabbioni, 2011). Many concepts of toxicology for the 21 $1^{\text {st }}$ century (Tox-21c) (Hartung, 2009a,b) can be applied: Figure 1 shows the toolbox of toxicology in the $21^{\text {st }}$ century, indicating also roughly the development needs and the complexity / costs of the methods. Many of these have been detailed in this series of articles as well as our workshop reports and shall not be reiterated here. The reader is referred to the respective papers for in vivo (Hartung, 2008a, 2013), in vitro (Hartung, 2007, 2013; Hartung and Leist, 2008; Leist et al., 2008) and in silico approaches (Hartung and Hoffmann, 2009; Hartung, 2016c), in vitro work for testing cosmetics (Hartung, 2008b), chemicals (Hartung, 2010b), nanomaterials (Hartung, 2010a; Hartung and Sabbioni, 2011), pharmaceuticals (Rovida et al., 2015b) and food (Hartung and Koëter, 2008), organo-typic cultures (Alépée et al., 2014; Andersen et al., 2014; Hartung, 2014; Marx et al., 2016), refinement of animal testing (Zurlo and Hutchinson, 2014), Integrated Testing Strategies (Hartung et al., 2013a; Rovida et al., 2015a), pathways of toxicity (Hartung and McBride, 2011; Kleensang et al., 2014; Tollefsen et al., 2014), omics technologies (Bouhifd et al., 2013, 2015a,b; Ramirez et al., 2013), and high-content imaging (van Vliet et al., 2014). These approaches come with different advantages and disadvantages in general and in particular for testing e-cigarettes (Tab. 2). Noteworthy, parts of e-cigarette industry have embraced concepts of Integrated Testing Strategies (Costigan and Meredith, 2015). Others are pursuing Systems Toxicology approaches (Iskander et al., 2016). However, no formal validations (Leist et al., 2012) have yet been undertaken. Both, validation of high-throughput methods (Judson et al., 2013) for the multitude of flavor chemicals, systematic reviews (Hartung and Hoffmann, 2009; Hoffmann et al., 2014; Stephens, 2013, 2016), and mechanistic validation of in vitro models (Hartung et al., 2013b) will need to be considered.

\section{E-cigarettes - the ugly duckling of public health?}

"Giving up smoking is the easiest thing in the world. I know because I've done it thousands of times." Mark Twain nicely coined it. Quitting is difficult and most tools have shown limited effect. Some early studies suggested that one in three smokers trying e-cigarettes lastingly reduces his/her smoking and one in nine changes completely. Thus, we have to do everything possible to encourage switching and avoid relapses. There should be no doubt that e-cigarettes play a very important role as a ces-

$15 \mathrm{http}: / /$ www.etoxproject.eu

16 http://www.fda.gov/TobaccoProducts/default.htm

17 https://www.epa.gov/chemical-research/toxicity-forecasting 
Tab. 3: Comparison of national policies on e-cigarettes

- US started regulating as tobacco product

- Europe twin track approach - from 2016 either consumer product or medicine

- Canada personal consumption legal - sales banned

- South Korea legal but heavily taxed

- Banned in Brazil, Hong Kong, Malaysia, Turkey, United Arabian Emirates

- Legal in China, India...

- WHO examining regulatory options

(Source: Deborah Arnott, Chief Executive, Action on Smoking \& Health ASH UK, at European Science Open Forum, Copenhagen, 2014. ASH is a British NGO dedicated to reducing the harm caused by tobacco set up by the Royal College of Physicians in 1971.)

sation tool (Rom et al., 2015). But should this be left to prescription controlled by physicians? This is certainly the safest way to avoid early trying out and use by non-smokers. However, it also misses the opportunity of broad use and reaching out to those not (yet) considering quitting, which is, from experience with other substitution products, the large majority. In the UK alone, it has been proposed that switching $1 \%$ of smokers annually from smoking to less harmful nicotine sources could potentially save approximately 60,000 lives in a decade (Fagerstrom and Bridgman, 2014).

It will be some years before we know how dangerous e-cigarettes are. Statements like "Three months of additional smoking poses a greater risk to someone's health, on average, than a lifetime of using a low-risk alternative." by David Sweanor, former Advisor to the WHO on Tobacco Control, are certainly wishful thinking. Let's take the $3-5 \%$ of health risk as a given for a moment, well accepting it could be $1 \%$ or $10 \%$. It brings the risk into the range of passive smoking, i.e., living as a nonsmoker with a smoker. Purists will still not be happy with a product that is more dangerous than anything we would allow to come to the market in any other industry. They are right. More pragmatic health professionals will see the opportunity to help many smokers to quit. They are right too. "It's not hard to make decisions when you know what your values are." (Roy Disney). I know what my values are - I would have loved to see my father with our 9-year-old on his lap only once in his life, if

Tab 4: European Twin Track for e-cigarettes from 2016

\begin{tabular}{|l|l|}
\hline $\begin{array}{l}\text { Tobacco Products Directive regulation of electronic } \\
\text { cigarettes }\end{array}$ & $\begin{array}{l}\text { MHRA licenced Nicotine Containing Products (NCPs) } \\
\text { including e-cigs }\end{array}$ \\
\hline Products not available on prescription & Products available on prescription \\
\hline $20 \%$ VAT & $5 \%$ VAT \\
\hline $\begin{array}{l}\text { Cross border advertising banned by 2016; up to Member States } \\
\text { to decide on domestic advertising (billboards, Point of Sale, } \\
\text { buses, etc.) }\end{array}$ & $\begin{array}{l}\text { Advertising allowed - under OTC rules so no celebrity or health } \\
\text { professional endorsement and no free samples; must be targeted } \\
\text { at adult smokers, etc. }\end{array}$ \\
\hline Products widely available & Products available on general sale (GSL) \\
\hline Cannot make health claims & Can make health claims \\
\hline $\begin{array}{l}\text { Upper limits for nicotine content will be set and likely to be in } \\
\text { force by } 2017\end{array}$ & MHRA regulation is flexible; there are no upper limits. \\
\hline $30 \%$ health warning about nicotine on front and back of packs & No health warnings on packs \\
\hline $\begin{array}{l}\text { Member States retain powers, e.g., on flavours, domestic } \\
\text { advertising }\end{array}$ & Flavors require marketing authorisation \\
\hline $\begin{array}{l}\text { Children and Families Bill allows for age of sale of } 18 \text { for nicotine } \\
\text { products }\end{array}$ & $\begin{array}{l}\text { Age of sale 12 but can be varied by product so could be higher for } \\
\text { electronic cigarettes }\end{array}$ \\
\hline
\end{tabular}

(Source: Deborah Arnott, Chief Executive, Action on Smoking \& Health ASH UK, at European Science Open Forum, Copenhagen, 2014. ASH is a British NGO dedicated to reducing the harm caused by tobacco set up by the Royal College of Physicians in 1971.) 
only something like e-cigarettes had been available. Therefore, I am happy to enter this compromise and try to help make this product as broadly available as possible by helping to minimize the clearly existing risks.

It is fascinating to see how different countries try to define the lines - from laissez-faire to banning; from high taxation to prescription only (Tab. 3). These are value and policy decisions made where there is no clear right or wrong. As toxicologists and public health professionals we have to advise policy. What we need to do this is data. Our traditional tools are not very helpful: Cancer testing in rats and mice? Almost everything is positive, e.g., $45 \%$ of prescription drugs. But cigarette smoking? No lung cancer in rats and mice, at least not reproducible enough to make a suitable model. And as discussed above, such studies are extremely costly, about $\$ 1$ million for one substance in one species for oral applications, \$2.5 million for inhalation studies. It is difficult to imagine that we could test all the flavors. And we would get the results only in four to five years as the treatment alone takes two years and evaluation of all organs takes another two years. The laboratory capacities worldwide to test for cancer effects are dozens of substances at the same time, not hundreds.

In the short term, (self-)restricting the use of additives and using fast cell- and computer-based evaluations of safety will help improve the safety of e-cigarettes. And in the medium term, controlled trials will be necessary. But if we wait for this evidence to emerge and prohibit or hinder the use of e-cigarettes, we would probably miss a tremendous opportunity to save lives on a large scale.

Some countries have obviously chosen to ban or make it very difficult to access e-cigarettes (Tab. 3). Lisa Wingate (in A Month of Summer) said nicely, "The hardest thing about the road not taken is that you never know where it might have led." Sure, we can wait and observe what the results in other countries are, but this would likely be paying an enormous toll in lives that could have been saved. "To ban e-cigarettes is like keeping the emergency exit closed, because the fire stairs are slippery" said Karl Erik Lund, Research Director at the Norwegian Institute for Alcohol and Drug Research. Europe has chosen a twin track approach, which gives producers and consumers the choice about which market they are in (Tab. 4).

It is important that regulation ensures easy access for smokers, but aims at restricting marketing to adult smokers only. Tobacco use is the leading cause of preventable disease and death in the United States, responsible for 480,000 deaths per year. In December 2010, the U.S. Court of Appeals ruled that FDA could not regulate electronic cigarettes as a drug or a device but only as a tobacco product. That meant the government could oversee their marketing but not restrict their sale, except to minors. The FDA issued in regulation for e-cigarettes May $2016^{18}$ :

- Not allowing products to be sold to persons under the age of

18 years (both in person and online), which was already law in 48 federal states, requiring age verification by photo ID;

- Not allowing the selling of covered tobacco products in vending machines (unless in an adult-only facility); and

- Not allowing the distribution of free samples.

- Registering manufacturing establishments and providing product listings to the FDA;

- Reporting ingredients, and harmful and potentially harmful constituents;

- Requiring premarket review and authorization of new tobacco products by the FDA;

- Placing health warnings on product packages and advertisements; and

- Not selling modified risk tobacco products (including those described as "light," "low," or "mild") unless authorized by the FDA.

The FDA rule also requires manufacturers of all products that entered the market after February 15, 2007 to show that the products meet the applicable public health standard set forth in the law and receive marketing authorization from the FDA. The tobacco product review process gives the agency the ability to evaluate important factors, such as ingredients, product design and health risks, as well as their appeal to youth and non-users. Noteworthy, the company can sell their product for two years while submitting and one year while the registration is under review.

The new rule by FDA will likely set standards for this industry that have worldwide impact. The guidance for assessing hazards of the chemicals used will be critical. Noteworthy, flavors have not been banned as they are for regular cigarettes with the exception of menthol. We as toxicologists have to facilitate communication of accurate information on relative risks and to encourage improvements in quality, safety and efficacy of the product supporting innovation. This will also facilitate international harmonization. At the same time, clinicians and epidemiologists need to monitor the market and emerging health problems closely.

As discussed, there are emerging new methods - cell cultures and computer models. They are heavily used for the new "low risk tobacco products"... by the tobacco industry. The old joke comes to mind: "Researchers now found that smoking is actually not hazardous - signed Dr. Marlboro". Can we believe them after all experiences of the past (Michaels, 2008)? They reach out to independent toxicologist like me, but taking their money is a no-go - for Johns Hopkins and for any researcher concerned with their reputation. The good thing is that the FDA started to control these products and takes money out of this industry to support independent research. This is a big step forward, hopefully fast enough to inform policy decisions on e-cigarette regulations in all parts of the world. WHO estimated in 2008 that one billion people were killed in the last century by tobacco smoking ${ }^{19}$. Bringing this down by $95 \%$ is an opportunity we cannot miss. But we should prune the

18 http://www.fda.gov/NewsEvents/Newsroom/PressAnnouncements/ucm499234.htm

19 http://www.who.int/tobacco/mpower/mpower_report_tobacco_crisis_2008.pdf 
wild growth of flavor and additive use, assessing their safety for inhalation quickly and objectively using $21^{\text {st }}$ century approaches. Perhaps e-cigarettes will then become the beautiful swan of public health.

\section{References}

Alépée, N., Bahinski, T., Daneshian, M. et al. (2014). State-ofthe-art of 3D cultures (organs-on-a-chip) in safety testing and pathophysiology - a $\mathrm{t}^{4}$ report. ALTEX 31, 441-477. http:// dx.doi.org/10.14573/altex1406111

Allen, J. G., Flanigan, S. S., LeBlanc, M. et al. (2016). Flavoring chemicals in e-cigarettes: Diacetyl, 2,3-pentanedione, and acetoin in a sample of 51 products, including fruit-, candy-, and cocktail-flavored e-cigarettes. Environ Health Persp 124, 1-7. http://dx.doi.org/10.1289/EHP348

Andersen, M., Betts, K., Dragan, Y. et al. (2014). Developing microphysiological systems for use as regulatory tools - challenges and opportunities. ALTEX 31, 364-367. http://dx.doi. org/10.14573/altex.1405151

Ball, N., Cronin, M. T. D., Shen, J. et al. (2016). Toward good read-across practice (GRAP) guidance. ALTEX 33, 149-166. http://dx.doi.org/10.14573/altex.1601251

Basketter D. A., Clewell, H., Kimber, I. et al. (2012). A roadmap for the development of alternative (non-animal) methods for systemic toxicity testing. ALTEX 29, 3-89. http://dx.doi. org/10.14573/altex.2012.1.003

Benowitz, N. L. (2010). Nicotine addiction. N Engl J Med 362, 2295-2303. http://dx.doi.org/10.1056/NEJMra0809890

Bottini, A. A., and Hartung, T. (2009). Food for thought ... on economics of animal testing. ALTEX 26, 3-16. http://www. altex.ch/Current-issue.50.html?iid=104\&aid=1

Bottini, A. A., and Hartung, T. (2010). The economics of animal testing. ALTEX, Spec Issue 27, 67-77.

Bouhifd, M., Hartung, T., Hogberg, H. T. et al. (2013). Review: Toxicometabolomics. J Appl Toxicol 33, 1365-1383. http:// dx.doi.org/10.1002/jat.2874

Bouhifd, M., Andersen, M. E., Baghdikian, C. et al. (2015a). The human toxome project. ALTEX 32, 112-124. http:// dx.doi.org/10.14573/altex.1502091

Bouhifd, M., Beger, R., Flynn, T. et al. (2015b). Quality assurance of metabolomics. ALTEX 32, 319-326. http://dx.doi. org/10.14573/altex.1509161

Burstyn, I. (2014). Peering through the mist: Systematic review of what the chemistry of contaminants in electronic cigarettes tells us about health risks. BMC Public Health 14, 18. http:// dx.doi.org/10.1186/1471-2458-14-18

Callahan-Lyon P. (2014). Electronic cigarettes: Human health effects. Tob Control 23, ii36-40. http://dx.doi.org/10.1136/ tobaccocontrol-2013-051470

Campain, J. A. (2004). Nicotine: Potentially a multifunctional carcinogen? Toxicol Sci 79, 1-3. http://dx.doi.org/10.1093/ toxsci/kfh106

Cantrell, F. L. (2014). Adverse effects of e-cigarette exposures. J Commun Health 39, 614-616. http://dx.doi.org/10.1007/ s10900-013-9807-5
Caponnetto, P., Auditore, R. and Russo, C. (2013). Efficiency and safety of an electronic cigarette (ECLAT) as tobacco cigarettes substitute: A prospective 12-month randomized control design study. PLoS One 8, e66317. http://dx.doi.org/10.1371/ journal.pone.0066317

Carr, E. R. (2014). E-cigarettes: Facts, perceptions, and marketing messages. Clin J Oncol Nursing 18, 112-116. http:// dx.doi.org/10.1188/14.CJON.112-116

Cases, M., Briggs, K., Steger-Hartmann, T. et al. (2014). The eTOX data-sharing project to advance in silico drug-induced toxicity prediction. Int J Mol Sci 15, 21136-21154. http:// dx.doi.org/10.3390/ijms151121136

Cervellati, F., Muresan, X. M., Sticozzi, C. et al. (2014). Comparative effects between electronic and cigarette smoke in human keratinocytes and epithelial lung cells. Toxicol In Vitro 28, 999-1005. http://dx.doi.org/10.1016/j.tiv.2014.04.012

Cheng, T. (2014). Chemical evaluation of electronic cigarettes. Tob Control 23, Suppl 2, ii11-7. http://dx.doi.org/10.1136/ tobaccocontrol-2013-051482

CORESTA (2004). The CORESTA e-cigarette task force. The rationale and strategy for conducting in vitro toxicology testing of tobacco smoke. http://www.coresta.org/Reports/IVT_ TF_Rationale-IVT- Testing-Tob.-Smoke_Report_Jun04.pdf

Costigan, S. and Meredith, C. (2015). An approach to ingredient screening and toxicological risk assessment of flavours in e-liquids. Regulat Toxicol Pharmacol 72, 361-369. http:// dx.doi.org/10.1016/j.yrtph.2015.05.018

Czogala, J., Goniewicz, M. L., Fidelus, B. et al. (2014). Secondhand exposure to vapors from electronic cigarettes. Nicotine Tob Res 16, 655-662. http://dx.doi.org/10.1093/ntr/ntt203

Egilman, D., Mailloux, C. and Valentin, C. (2007). Popcornworker lung caused by corporate and regulatory negligence: An avoidable tragedy. Int J Occup Environ Health 13, 85-98. http://dx.doi.org/10.1179/oeh.2007.13.1.85

Fagerstrom, K. O. and Bridgman, K. (2014). Tobacco harm reduction: The need for new products that can compete with cigarettes. Addict Behav 39, 507-511. http://dx.doi. org/10.1016/j.addbeh.2013.11.002

Farsalinos, K. E. and Polosa, R. (2014). Safety evaluation and risk assessment of electronic cigarettes as tobacco cigarette substitutes: A systematic review. Therap Adv Drug Safety 5, 67-86. http://dx.doi.org/10.1177/2042098614524430

Freedman, N. D., Park, Y., Abnet, C. C. et al. (2012). Association of coffee drinking with total and cause-specific mortality. N Engl J Med 366, 1891-1904. http://dx.doi.org/10.1056/ NEJMoa1112010

Goniewicz, M. L., Knysak, J., Gawron, M. et al. (2014). Levels of selected carcinogens and toxicants in vapour from electronic cigarettes. Tob Control 23, 133-139. http://dx.doi. org/10.1136/tobaccocontrol-2012-050859

Gordon, S., Daneshian, M., Bouwstra, J. et al. (2015). Nonanimal models of epithelial barriers (skin, intestine and lung) in research, industrial applications and regulatory toxicology. ALTEX 32, 327-378. http://dx.doi.org/10.14573/ altex. 1510051

Hahn, J., Monakhova, Y. B., Hengen, J. et al. (2014). Electronic 
cigarettes: Overview of chemical composition and exposure estimation. Tob Induced Dis 12, 23. http://dx.doi.org/10.1186/ s12971-014-0023-6

Hartung, T. (2007). Food for thought ... on cell culture. ALTEX 24, 143-147. http://www.altex.ch/All-issues/Issue.50. html?iid=87\&aid=2

Hartung, T. (2008a). Food for thought ... on animal tests. ALTEX 25, 3-9. http://www.altex.ch/All-issues/Issue.50. html?iid=98\&aid=1

Hartung, T. (2008b). Food for thought ... on alternative methods for cosmetics safety testing. ALTEX 25, 147-162. http:// www.altex.ch/All-issues/Issue.50.html?iid=101\&aid=1

Hartung, T. and Koëter, H. (2008). Food for thought ... on alternative methods for food safety testing. ALTEX 25, 259-264. http://www.altex.ch/All-issues/Issue.50.html?iid=103\&aid=1

Hartung, T. and Leist, M. (2008). Food for thought ... on the evolution of toxicology and phasing out of animal testing. ALTEX 25, 91-96. http://www.altex.ch/All-issues/Issue.50. html?iid=99\&aid=1

Hartung, T. (2009a). Toxicology for the twenty-first century. Nature 460, 208-212. http://dx.doi.org/10.1038/460208a

Hartung, T. (2009b). A toxicology for the $21^{\text {st }}$ century: Mapping the road ahead. Toxicol Sci 109, 18-23. http://dx.doi. org/10.1093/toxsci/kfp059

Hartung, T. and Hoffmann, S. (2009). Food for thought on ... in silico methods in toxicology. ALTEX 26, 155-166. http:// www.altex.ch/Current-issue.50.html?iid=107\&aid=1

Hartung, T. (2010a). Food for thought ... on alternative methods for nanoparticle safety testing. ALTEX 27, 87-95. http://www. altex.ch/Current-issue.50.html?iid=113\&aid=1

Hartung, T. (2010b). Food for thought ... on alternative methods for chemical safety testing. ALTEX 27, 3-14. http://www. altex.ch/Current-issue.50.html?iid=112\&aid=1

Hartung, T. and McBride, M. (2011). Food for thought ... on mapping the human toxome. ALTEX 28, 83-93. http://dx.doi. org/10.14573/altex.2011.2.083

Hartung, T. and Sabbioni, E. (2011). Alternative in vitro assays in nanomaterial toxicology. WIREs Nanomed Nanobiotechnol 3, 545-573. http://dx.doi.org/10.1002/wnan.153

Hartung, T., van Vliet, E., Jaworska, J. et al. (2012). Systems toxicology. ALTEX 29, 119-128. http://dx.doi.org/10.14573/ altex.2012.2.119

Hartung, T. (2013). Look back in anger - what clinical studies tell us about preclinical work. ALTEX 30, 275-291. http:// dx.doi.org/10.14573/altex.2013.3.275

Hartung, T., Luechtefeld, T., Maertens, A. and Kleensang, A. (2013a). Integrated testing strategies for safety assessments. ALTEX 30, 3-18. http://dx.doi.org/10.14573/altex.2013.1.003

Hartung, T., Stephens, M. and Hoffmann, S. (2013b). Mechanistic validation. ALTEX 30, 119-130. http://dx.doi. org/10.14573/altex.2013.2.119

Hartung, T. (2014). 3D - A new dimension of in vitro research. Adv Drug Deliv Rev 69, vi. http://dx.doi. org/10.1016/j.addr.2014.04.003

Hartung, T. (2016a). Can we wait for e-cigarette trials? Chem- istry World. http://www.rsc.org/chemistryworld/2016/04/ electronic-cigarettes-trials-vaping-safety-data

Hartung, T. (2016b). E-cigarettes - the ugly duckling of public health? Scientific American, in press.

Hartung, T. (2016c). Making big sense from big data in toxicology by read-across. ALTEX 33, 83-93. http://dx.doi. org/10.14573/altex.1603091

Hecht, S. S., Carmella, S. G., Kotandeniya, D. et al. (2015). Evaluation of toxicant and carcinogen metabolites in the urine of e-cigarette users versus cigarette smokers. Nicotine Tob Res 17, 704-709. http://dx.doi.org/10.1093/ntr/ntu218

Hoffmann, S., Stephens, M. and Hartung, T. (2014). Evidencebased Toxicology. In P. Wexler (ed). Encyclopedia of Toxicology (565-567). $3^{\text {rd }}$ edition, vol 2. Elsevier Inc., Academic Press. http://dx.doi.org/10.1016/b978-0-12-386454-3.010605

Hutzler, C., Paschke, M., Kruschinski, S. et al. (2014). Chemical hazards present in liquids and vapors of electronic cigarettes. Arch Toxicol 88, 1295-1308. http://dx.doi.org/10.1007/ s00204-014-1294-7

Iskandar, A. R., Gonzalez-Suarez, I., Majeed, S. et al. (2016). A framework for in vitro systems toxicology assessment of e-liquids. Toxicol Mechan Meth, 1-24. http://dx.doi.org/10.3 109/15376516.2016.1170251

Jasinska, A. J., Zorick, T., Brody, A. L. and Stein, E. A. (2014). Dual role of nicotine in addiction and cognition: A review of neuroimaging studies in humans. Neuropharmacol 84, 111122. http://dx.doi.org/10.1016/j.neuroph arm.2013.02.015

Ji, E. H., Sun, B., Zhao, T. et al. (2016). Characterization of electronic cigarette aerosol and its induction of oxidative stress response in oral keratinocytes. PLoS One 11, e 0154447. http://dx.doi.org/10.1371/journal.pone.0154447

Johnson, M. D., Schilz, J., Djordjevic, M. V. et al. (2009). Evaluation of in vitro assays for assessing the toxicity of cigarette smoke and smokeless tobacco. Canc Epidem Biomarkers Prevention 18, 3263-3304. http://doi.org/10.1158/1055-9965. EPI-09-0965

Judson, R., Kavlock, R., Martin, M. et al. (2013). Perspectives on validation of high-throughput pathway-based assays supporting the $21^{\text {st }}$ century toxicity testing vision. ALTEX 30, 51-66. http://dx.doi.org/10.14573/altex.2013.1.051

Kim, J. W. and Baum, C. R. (2015). Liquid nicotine toxicity. Pediatric Emergency Care 31, 517-521. http://doi. org/10.1097/PEC.0000000000000486

Kleensang, A., Maertens, A., Rosenberg, M. et al. (2014). Pathways of toxicity. ALTEX 31, 53-61. http://dx.doi. org/10.14573/altex.1309261

Krause, M. J. and Townsend, T. G. (2015). Hazardous waste status of discarded electronic cigarettes. Waste Manag 39, 57-62. http://dx.doi.org/10.1016/j.wasman.2015.02.005

Larsson, S. C. and Wolk, A. (2007). Coffee consumption and risk of liver cancer: A meta-analysis. Gastroenterol 132, 1740-1745. http://dx.doi.org/10.1053/j.gastro.2007.03.044

Leist, M., Hartung, T. and Nicotera, P. (2008). The dawning of a new age of toxicology. ALTEX 25, 103-114. http://www. 
altex.ch/All-issues/Issue.50.html?iid=99\&aid=3

Leist, M., Hasiwa, M., Daneshian, M. and Hartung, T. (2012). Validation and quality control of replacement alternatives current status and future challenges. Toxicol Res 1, 8. http:// dx.doi.org/10.1039/c2tx20011b

Leist, M., Hasiwa, N., Rovida, C. et al. (2014). Consensus report on the future of animal-free systemic toxicity testing. ALTEX 31, 341-356. http://dx.doi.org/10.14573/altex.1406091

Lerner, C. A., Sundar, I. K., Yao, H. et al. (2015). Vapors produced by electronic cigarettes and e-juices with flavorings induce toxicity, oxidative stress, and inflammatory response in lung epithelial cells and in mouse lung. PLoS One 10, e0116732. http://dx.doi.org/10.1371/journal.pone.0116732

Levy, D. T., Mumford, E. A., Cummings, K. M. et al. (2004). The relative risks of a low-nitrosamine smokeless tobacco product compared with smoking cigarettes: Estimates of a panel of experts. Cancer Epidemiol Biomarkers Prevent 13, 2035-2042.

Loftfield, E., Freedman, N. D., Graubard, B. I. et al. (2015). Coffee drinking and cutaneous melanoma risk in the NIHAARP diet and health study. J Natl Cancer Inst 107, 1-9. http://dx.doi.org/10.1093/jnci/dju421

Luechtefeld, T., Maertens, A., Russo, D. P. et al. (2016). Global analysis of publicly available safety data for 9,801 substances registered under REACH from 2008-2014. ALTEX 33, 95109. http://dx.doi.org/10.14573/altex.1510052.

Maertens, A., Anastas, N., Spencer, P. J. et al. (2014). Green toxicology. ALTEX 31, 243-249. http://dx.doi.org/10.14573/ altex.1406181

Marx, U., Andersson, T. B., Bahinski, A. et al. (2016). Biology-inspired microphysiological system approaches to solve the prediction dilemma of substance testing using animals. ALTEX 33, 272-321. http://dx.doi.org/10.14573/altex.1603161

Mayer, B. (2014). How much nicotine kills a human? Tracing back the generally accepted lethal dose to dubious self-experiments in the nineteenth century. Arch Toxicol 88, 5-7. http:// dx.doi.org/10.1007/s00204-013-1127-0

McNeill, A., Brose, L. S., Calder, R. et al. (2015). E-cigarettes: An evidence update. A report commissioned by Public Health England. https://www.gov.uk/government/uploads/ system/uploads/attachment_data/file/457102/Ecigarettes an_evidence_update_A_report_commissioned_by_Public_ Health_England_FINAL.pdf

Michaels, D. (2008). Doubt Is Their Product: How Industry's Assault on Science Threatens Your Health. Oxford University Press.

Nelson, N. (2014). More questions than answers surrounding e-cigarette debate. J Natl Cancer Inst, dju101-dju101. http:// doi.org/10.1093/jnci/dju101

Neltner, T. G., Alger, H. M., Leonard, J. E. and Maffini, M. V. (2013). Data gaps in toxicity testing of chemicals allowed in food in the United States. Reprod Toxicol 42, 85-94. http:// doi.org/10.1016/j.reprotox.2013.07.023

Nkondjock, A. (2009). Coffee consumption and the risk of cancer: An overview. Cancer Lett 277, 121-125. http://dx.doi. org/10.1016/j.canlet.2008.08.022

Orr, M. S. (2014). Electronic cigarettes in the USA: A summary of available toxicology data and suggestions for the future. Tob Control 23, Suppl 2, ii18-22. http://doi.org/10.1136/tobaccocontrol-2013-051474

Palpant, N. J., Hofsteen, P., Pabon, L. et al. (2015). Cardiac development in zebrafish and human embryonic stem cells is inhibited by exposure to tobacco cigarettes and e-cigarettes. PLoS One 10, e0126259. http://dx.doi.org/10.1371/journal. pone. 0126259

Patlewicz, G., Ball, N., Becker, R. A. et al. (2014). Readacross approaches - misconceptions, promises and challenges ahead. ALTEX 31, 387-396. http://dx.doi. org/10.14573/altex.1410071

Polosa, R., Caponnetto, P., Morjaria, J. B. et al. (2011) Effect of an electronic nicotine delivery device (e-cigarette) on smoking reduction and cessation: A prospective 6-month pilot study. BMC Public Health 11, 786. http://dx.doi.org/10.1186/14712458-11-786

Ramirez, T., Daneshian, M., Kamp, H. et al. (2013). Metabolomics in toxicology and preclinical research. ALTEX 30, 209-225. http://dx.doi.org/10.14573/altex.2013.2.209

Rom, O., Pecorelli, A., Valacchi, G. and Reznick, A. Z. (2015). Are E-cigarettes a safe and good alternative to cigarette smoking? Ann New York Acad Sci 1340, 65-74. http://dx.doi. org/10.1111/nyas.12609

Rovida, C. and Hartung, T. (2009). Re-evaluation of animal numbers and costs for in vivo tests to accomplish REACH legislation requirements for chemicals - a report by the transatlantic think tank for toxicology $\left(\mathrm{t}^{4}\right)$. ALTEX 26, 187-208. http://www.altex.ch/Current-issue.50.html?iid=107\&aid=4

Rovida, C., Alépée, N., Api, A. M. et al. (2015a). Integrated Testing Strategies (ITS) for safety assessment. ALTEX 32, 171-181. http://dx.doi.org/10.14573/altex.1506201

Rovida, C., Asakura, C., Daneshian, M. et al. (2015b). Toxicity testing in the $21^{\text {st }}$ century beyond environmental chemicals. ALTEX 32, 25-40. http://dx.doi.org/10.14573/altex.1411011

Sanner, T. and Grimsrud, T. K. (2015). Nicotine: Carcinogenicity and effects on response to cancer treatment - a review. Front Oncology 5, 196. http://doi.org/10.3389/fonc.2015.00196

Schroeder, M. J. and Hoffman, A. C. (2014). Electronic cigarettes and nicotine clinical pharmacology. Tob Control 23, Suppl 2, ii30-5. http://dx.doi.org/10.1136/tobaccocontrol-2013-051469

Shiffman, S., Sembower, M. A., Pillitteri, J. L. et al. (2015). The impact of flavor descriptors on nonsmoking teens' and adult smokers' interest in electronic cigarettes. Nicotine Tob Res 17, 1255-1262. http://dx.doi.org/10.1093/ntr/ntu333

Song, F., Qureshi, A. A. and Han, J. (2012). Increased caffeine intake is associated with reduced risk of basal cell carcinoma of the skin. Cancer Res 72, 3282-3289. http://dx.doi. org/10.1158/0008-5472.CAN-11-3511

Stephens, M. L., Andersen, M., Becker, R. A. et al. (2013). Evidence-based toxicology for the $21^{\text {st }}$ century: Opportunities and challenges. ALTEX 30, 74-104. http://dx.doi. org/10.14573/altex.2013.1.074 
Stephens, M. L., Betts, K., Beck, N. B. et al. (2016). The emergence of systematic review in toxicology. Toxicol Sci, in press. http://dx.doi.org/10.1093/toxsci/kfw059

Sussan, T. E., Gajghate, S., Thimmulappa, R. K. et al. (2015). Exposure to electronic cigarettes impairs pulmonary anti-bacterial and anti-viral defenses in a mouse model. PLoS One 10, e0116861. http://dx.doi.org/10.1371/journal.pone.0116861

Tierney, P. A., Karpinski, C. D., Brown, J. E. et al. (2015). Flavour chemicals in electronic cigarette fluids. Tob Control 0, 1-6. http://dx.doi.org/10.1136/tobaccocontrol-2014-052175

Tollefsen, K. E., Scholz, S., Cronin, M. T. et al. (2014). Applying adverse outcome pathways (AOPs) to support integrated approaches to testing and assessment (IATA). Reg Toxicol Pharmacol 70, 629-640. http://dx.doi.org/10.1016/j. yrtph.2014.09.009

van Vliet, E., Daneshian, M., Beilmann, M. et al. (2014). Current approaches and future role of high content imaging in safety sciences and drug discovery. ALTEX 31, 479-493. http://dx.doi.org/10.14573/altex.1405271

Vardavas, C. I., Filippidis, F. T. and Agaku, I. T. (2015). Determinants and prevalence of e-cigarette use throughout the European Union: A secondary analysis of 26566 youth and adults from 27 countries. Tob Control 24, 442-448. http:// dx.doi.org/10.1136/tobaccocontrol-2013-051394

Wan, J., Johnson, M., Schilz, J. et al. (2009). Evaluation of in vitro assays for assessing the toxicity of cigarette smoke and smokeless tobacco. Cancer Epidemiol Biomarkers Prev 18, 3263-3304. http://dx.doi.org/10.1158/1055-9965.EPI-090965
Werley, M. S., Kirkpatrick, D. J., Oldham, M. J. et al. (2016). Toxicological assessment of a prototype e-cigaret device and three flavor formulations: A 90-day inhalation study in rats. Inhal Toxicol 28, 22-38. http://dx.doi.org/10.3109/08 958378.2015.1130758

Witschi, H. (2007). Tobacco smoke-induced lung cancer in animals - a challenge to toxicology (?). Int J Toxicol 26, 339344. http://dx.doi.org/10.1080/10915810701490380

Zhu, H., Bouhifd, M., Kleinstreuer, N. et al. (2016). Supporting read-across using biological data. ALTEX 33, 167-182. http:// dx.doi.org/10.14573/altex.1601252

Zhu, S.-H., Sun, J. Y., Bonnevie, E. et al. (2014). Four hundred and sixty brands of e-cigarettes and counting: Implications for product regulation. Tob Control 23, Suppl 3, iii3-9. http:// dx.doi.org/10.1136/tobaccocontrol-2014-051670

Zurlo, J. and Hutchinson, E. (2014). The state of animal welfare in the context of refinement. ALTEX 31, 4-10. http://dx.doi. org/10.14573/altex.1312191

\section{Conflict of interest}

The author has no conflict of interest to declare.

\section{Correspondence to}

Thomas Hartung, MD PhD

Center for Alternatives to Animal Testing

Johns Hopkins Bloomberg School of Public Health 615 N. Wolfe Str.

Baltimore, MD, 21205, USA

e-mail: thartun1@jhu.edu 